\title{
Correction: Tofacitinib for the treatment of moderately to severely active ulcerative colitis: a systematic review, network meta-analysis and economic evaluation
}

Lohan C, Diamantopoulos A, LeReun C, et al. Tofacitinib for the treatment of moderately to severely active ulcerative colitis: a systematic review, network metaanalysis and economic evaluation. BMJ Open Gastro 2019;6:e000302. doi: 10.1136/ bmjgast-2019-000302

This article was previously published with incorrect information regarding dosing values in the main body, Tables 2 and 9, footnote of Figure 1 and supplementary material.

The correct dosage, considered in the analysis, was $5 \mathrm{mg} / \mathrm{kg}$ given as an intravenous infusion induction regimen at 0,2 , and 6 weeks followed by a maintenance regimen of $5 \mathrm{mg} / \mathrm{kg}$ IV every 8 weeks thereafter.

Open access This is an open access article distributed in accordance with the Creative Commons Attribution Non Commercial (CC BY-NC 4.0) license, which permits others to distribute, remix, adapt, build upon this work non-commercially, and license their derivative works on different terms, provided the original work is properly cited, appropriate credit is given, any changes made indicated, and the use is non-commercial. See: http:// creativecommons.org/licenses/by-nc/4.0/.

C Author(s) (or their employer(s)) 2020. Re-use permitted under CC BY-NC. No commercial re-use. See rights and permissions. Published by BMJ.

BMJ Open Gastro 2020;7:e031032corr1. doi:10.1136/bmjgast-2019-000302corr1

D Check for updates 